\title{
THE IMPACT OF FAMILY AND PEER SUPPORTS IN REDUCING DEPRESSION AMONG OSTEOARTHRITIS PATIENTS
}

\author{
Wahyu Tri Sudaryanto'), Ambar Mudigdo²), \\ RB Soemanto3), Bhisma Murti4) \\ ${ }^{1)}$ Study Program in Physiotherapy, Universitas Muhammadiyah Surakarta \\ 2)Faculty of Medicine, Universitas Sebelas Maret \\ 3)Faculty of Social and Political Sciences, Universitas Sebelas Maret \\ 4)Masters Program in Public Health, Universitas Sebelas Maret
}

\begin{abstract}
Background: Previous studies found that anxiety or depression were highly prevalent among osteoarthritis (OA) patients. This study aimed to examine the impact of family and peer support in reducing depression among OA patients.

Subjects and Method: A case-control study was conducted at Dr. Moewardi Hospital and Dr. Soeharso Orthopedic Hospital, Surakarta, Central Java, from January to February 2018. A sample of 200 OA patients was selected by simple random sampling. The dependent variables were depression. The independent variables were pain level, functional disability, family support, and peer support. Data on depression were measured by Beck's Depression Inventory (BDI). Functional disability data were measured by The Western Ontario and McMaster University Arthritis Index (WOMAC). The other variables were collected by questionnaire. The data were analyzed by path analysis, run on Stata 13.

Results: Family support ( $\mathrm{b}=-0.75 ; 95 \% \mathrm{CI}=-1.39$ to $-0.11 ; \mathrm{p}=0.022$ ) and peer support $(b=-1.25 ; 95 \% \mathrm{CI}=-1.90$ to $-0.59 ; \mathrm{p}<0.001)$ reduced depression in OA patients. Pain level was indirectly and positively associated with depression $(b=1.54 ; 95 \% \mathrm{CI}=0.88$ to 2.20; $\mathrm{p}<0.001$ ) through functional disability.

Conclusion: Family support and peer support reduce depression in OA patients.
\end{abstract}

Keywords: depression, family support, peer support, osteoarthritis

Correspondence:

Wahyu Tri Sudaryanto. Study Program in Physiotherapy, Universitas Muhammadiyah Surakarta, Central Java. Email: wahyu.londho86@yahoo.co.id. Mobile: 085640637769.

The $5^{\text {th }}$ International Conference on Public Health Best Western Premier Hotel, Solo, Indonesia, February 13-14, 2019 | 138 https://doi.org/10.26911/theicph.2019.01.45 